\title{
Foreignized or Domesticated: Investigating Translation for Enhancing Artistic Dialogue
}

\author{
Li Pan \\ University of Macau \& Guangdong University of Foreign Studies
}

\begin{abstract}
Translation plays a significant role in intercultural communication for it not only enables two cultures to converse with each other but also helps to reveal the disparity and unbalance between cultures. This is especially true in the case of translation of texts for the performing arts like theatre, dance, opera, and music, etc., which are usually embedded with condensed culture specific expressions and concepts. Examining translation strategies used in rendering such texts in practice can be quite revealing about the unbalance and inequality of interaction among or between cultures in a given community since the strategies employed by translators reflect the social cultural context in which texts are produced (Bassnett \& Trivedi 1999: 6). It is thus interesting to investigate the translation practice in a international community like Hong Kong, a city well-
\end{abstract}

\section{Li PAN}

English Department, Faculty of Social Sciences and Humanities, University of Macau, Macao / Faculty of English Language and Culture, Guangdong University of Foreign Studies, Guangzhou, China Phone: 853-62514585 / 86-13580300028; jacypan2000@gmail.com

Received Nov. 2010; Reviewed Dec. 2010; Revised version received Dec. 2010. 
known as a melting pot which is susceptible to the influences of both the Eastern and the Western cultures, and to find out which culture is more influential on translation practice in such a community and what strategies are deployed in translating texts for the performing arts in this community? However, up till now, not much research has been carried out addressing the impact of the cultural disparity or unbalance on the translation of texts for the arts in Hong Kong, nor the actual practice of translating promotional texts for the performing arts. The present study examines and compares the strategies and methods used in translating articles to publicize Ballet and Chinese Opera performances in the Hong Kong Arts Festival. A detailed textual analysis of the sample texts is given, followed by the discussion about the possible factors responsible for choosing different strategies in translating texts for the arts of Chinese origin and that of Western origins. The findings of the paper could shed some lights on the role of translation in the reporting of conflicts across cultural divides in translation of texts for the arts.

Keywords: translation strategies; promotional texts for performing arts; cultural disparity

\section{Introduction}

“...For too long translation was seen as purely an aesthetic act, and ideological problems were disregarded. Yet the strategies employed by translators reflect the context in which texts are produced"

(Bassnett \& Trivedi 1999: 6)

Hong Kong, an international city well-known as a melting pot, is influenced by both the Eastern and the Western cultures (Gibbons 1987: vii). However, scarcely any systemic studies have been carried out on the impact of the cultural disparity on the translation of texts in the arts in Hong Kong, nor does our literature review 
found any research concerning the actual practice of translation of texts for programme publicity.

The present paper investigates translation methods and strategies used in rendering texts in the arts used to publicize the programmes of the Hong Kong Arts Festival (hereinafter HKAF). ${ }^{1}$ It is prompted by an observation of the lack of sufficient correspondence in various ways between the English and Chinese versions of the articles on the website of the HKAF (http://www.hk.artsfestival.org/). The present paper, however, does not purport to criticize the nonequivalence of the ST and the TT but, incorporating the detailed textual analysis of the sample website articles and the findings from an enlarged data from the same arts event, examines first the methods and then the strategies used in translating such cultural loaded texts. Discussion then follows up on the possible impact that the disparity of Chinese and Western cultures as well as the promotional nature of texts themselves might have on the translations examined in the present study. It thus suggests that the right choice of strategies and methods is a guarantee of the success of the promotion of the arts event.

The research questions of the present project include the following. 1) Given the obvious adaptation in translating publicityrelated texts, what are the specific methods used to adapt to the receiving culture in translation of texts for promoting an artistic programme in HKAF? 2) Are different translation methods and strategies used in translating texts about programmes of Chinese origins from Chinese to English and those of Western origins from English to Chinese? 3) If the answer to Question 2 is yes, then does cultural disparity and inequality play a role in the choice of

\footnotetext{
${ }^{1}$ Hong Kong Arts Festival (HKAF), according its website (http://www.hk. artsfestival.org/en/about/), is a term used both to refer to the producer and the arts event itself, as the Hong Kong Arts Festival is introduced as "a non-profitable organization" and "a major international arts festival" held annually during February and March.
} 
different strategies in translation of texts of arts of different origins?

\section{Related Concepts}

\subsection{Texts in the Arts and Promotional Texts}

With a social linguistic approach, texts in this paper are inspected as language in actual use, and understood from the perspective how language functions in its social-cultural context. The English and Chinese versions of the articles on the website of the HKAF function both as texts for the arts and texts for promoting the Festival programmes. Texts in the arts here mainly refer to any public discourse related to an artistic form and meant for consumption by the public. In this sense, investigating translation of texts in the arts involves examining how different languages are employed in their own social-cultural contexts to achieve the designated purpose related to the arts. Texts for promotion, or promotional texts, refer to any discourse produced for the purpose of advertising or publicizing a particular product. Promotion, according to Oxford Advanced Learners Dictionary of Current English (2004), is defined as "advertising or publicity campaign for a particular product", and both advertising and publicity is intended to "provide information in order to attract public attention". Programme promotion in this paper is thus an equivalent of programme publicity, which refers to the activity of providing information about programmes to attract the potential audience's attention. With the noble mission of serving "as a catalyst to arouse wider public interest in the arts and to encourage artistic dialogue and cultural exchange" (HKAF website), the HKAF virtually still needs to take ticket sales as "a significant source of income" (ibid.). Under such a circumstance, to sell tickets is a purpose just as important as to "encourage artistic dialogue and cultural exchange" and to "present 
an annual international festival of the highest standard for the enrichment of cultural life in Hong Kong." This reality justifies the function of its website articles about the programmes, namely, to sell tickets. It has also been admitted frankly by our interviewee Daisy Chou, who was the chief editor of the articles: "They (the articles) are advertisements used to attract the audience to buy tickets." Therefore, we can say that "the website articles by the HKAF function as promotional texts, having the same purpose as any press release, feature articles, advertisements, invitations, flyers, brochures, etc."

\subsection{Cultural Disparity}

Translations, as pointed out by Bassnett \& Trivedi (1999: 6), are always produced within the cultural and political systems and therefore ideological problems should not be disregarded in translation studies. The inequality between ideological and cultural influences is one of the main concerns to postcolonial translation theorists. They argue that, as a result of colonial and postcolonial history, inequality has been the essential feature of the relationships between Western and Eastern languages and cultures, a fact that is bound to have impact on the translation practice (Jacquemond 1992: 140).

Douglas Robinson, the author of Translation and Empire (1997), goes further to point out that even after the collapse of colonialism, translation still functions as an instrument for further cultural inequalities in the contemporary world. As a result, acculturation (Samovar and Porter 2000: 45), ${ }^{2}$ one of the three types of culture changes, becomes the dominant one in cultural exchange between

\footnotetext{
${ }^{2}$ Acculturation "occurs when a society undergoes drastic culture change under the influence of a more dominant culture and society with which it has come in contact" (Samovar \& Porter 2000: 45)
} 
"weak" cultures and "strong" cultures, in which the strong ones get the upper hand, while the weak ones face the danger of being assimilated and losing their peculiarities.

Venuti's perception of the inequality of cultural influences between cultures on translation is also quite illuminating (Gentler 1993: 38). He expounds how aesthetic and cultural Otherness has been controlled and suppressed by translation. According to his research, most of the English translations that have been published since World War II implement fluent translation strategies, maintaining the cultural dominance of Anglo-American individualism, representing foreign cultures with ideological discourse specific to English cultures, but concealing all these determinations that effect under the veil of transparency (Venuti 1992: 6).

Inequality in translation is highly evident in the disproportion in the number of words translated between the East and the West. Richard Jacquemond offers highly productive schemas regarding this aspect (1992: 139-40). Generally speaking, the weak cultures tend to translate and introduce the strong cultures while the case is converse to the strong cultures.

Translation patterns since World War II indicate the overwhelming domination of English-language cultures. English has become the most translated language worldwide, but it is one the least translated into (Jacquemond 1992: 139-40). Thus, British and American publishing has reaped the financial benefits of successfully imposing Anglo-American cultural values on a vast foreign readership, while producing cultures in the United Kingdom and the United States that are aggressively monolingual, unreceptive to the foreign, accustomed to fluent translations that invisibly inscribe foreign texts with English-language values and provide readers with the narcissistic experience of recognizing their own culture in cultural other (Venuti, 1995: 15). The increasing voracity of English to assimilate all cultures, to become the single vehicle of cosmopolitanism is a threat to cultural differences (Simon 1997: 474). 
Enlightened by these studies of foreign translation theorists, Chinese scholars have also begun to study the influence the disparity between cultures wields on translation. Many have taken the English to Chinese literary translation in China as their subject, applied these theories to their study critically and produced encouraging results (Wang 2000; Han 2000). Han Ziman, however, holds that as translat ion scholars of a weak culture, we should pay attention to the dangerous situation we are facing and make efforts to strengthen our cultural influence (2000).

\subsection{Translation Strategies}

Strategy refers to a macro-guidance to an activity. It is about choice, which reflects context and affects outcomes. As to translation strategy, the pair of terms traditionally used is "literal translation" and "free translation" (Loh 1958), or "direct translation" and "oblique translation" (Vinay \& Darbelnet 1958) which describes as well as prescribes the transformation of form from the ST to the TT (Zhang \& Pan 2009). In the study of translation in terms of cultural influences, "domestication" and "foreignization", coined by Venuti (1997), are considered a pair of terminologies that can better describe the cultural relationship between the ST and the TT. According to Venuti, domestication leads to a fluent and transparent translation and makes the foreign familiar, in which the foreign culture are lessened and even erased and translated into cultural elements comply with the target language. On the contrary, by foreignization the translation keeps the cultural factors of the source language and the target readers know more about the foreign culture. Under foreignization strategy, translation methods are developed to exclude the dominant cultural values in the target language as it highlights the foreign identity of the source text and protects it from the ideological dominance of the target culture. Apparently, domestication is target culture oriented and foreignization source 
culture oriented.

This distinction between domestication and foreignization were attempted by Venuti to expose the unbalance and inequality of interaction among cultures. The strategy of foreignization is proposed "because it challenges the target-language culture even as it enacts its own ethnocentric violence on the foreign text" (Gentzler 19993: 38). Venuti points out that after a century of British colonial rule and nearly a century of American (indirect or neo-colonial) global rule, the translations entering English are greatly domesticated. Domestication strategy not only eradicates cultural and linguistic differences, but also creates a buffer zone of assimilated "sameness" around them (1997). In this way diversity is gradually leached out of the world, and we are all immeasurably impoverished (Robinson 1997: 109).

\section{Pilot Study}

\subsection{Sample Data and Text Analysis Method}

The sample retrieved from the website of the HKAF consists of the English and Chinese texts introducing the ballet and Jingju ${ }^{3}$ (known as "Beijing Opera" or "Peking Opera" in English) programmes staged in the 2008 HKAF. Texts for programmes of these two artistic forms are chosen chiefly for the reason that both of them represent performing arts of high achievement with hundreds year of history. Jingju, arising in the late 18th century (Goldstein 2007), is an art form most representative of Chinese traditional culture. The

\footnotetext{
${ }^{3}$ Though "Beijing opera" or "Peking opera" is the English term for the art form and the term entered the Oxford English Dictionary" in 1953, I prefer using "Jingju" to refer to the form in considering its uniqueness as a performing art, which consists of stylized, strongly rhythmical movements, concise and precise composition, fictitious plots, and interesting and engaging characters.
} 
most outstanding characteristic is that this art synthesizes and harmonizes dance, song, theatre, mime, martial arts and poetry, and the vocal techniques; its rhythms and melodies vary according to the thoughts and feelings of the characters. Originally staged for the court, it was extremely popular in the Qing Dynasty (1944-1911) court and has come to be regarded as one of the cultural treasures of China due to its highly achieved performance (Mackerras 1976). Yet, in the West, it is one of the least understood of the world's dramatic arts (Liu and $\mathrm{Tu}$ 2006). Ballet, originated in the Italian Renaissance courts of the 15th century and further developed in France, England, and Russia also as a concert dance form, has become a highly technical form of dance with its own vocabulary. Different from Jingju, it has been influential as a form of dance globally, and is taught in ballet schools around the world (Bland 1976).

The pilot part of the present study uses qualitative approach as the research method for only one text that gives introduction to the programmes of ballet and one to those of Jingju that staged in the 2008 HKAF. A detail text analysis of the English and Chinese versions of the two texts is conducted below with a focus on translation methods. The preliminary findings out of the pilot analysis is then tested by further examination which includes a larger data both from the upcoming $2011 \mathrm{HKAF}$ and from previous years.

To examine the possible acculturation in the cultural exchange through the website articles in the Festival in question, we compare their Chinese and English versions to find out the difference in providing information, and categorize the methods responsible for change in informativity ${ }^{4}$ in translation into two major types, namely, generalization and specification. While various methods can be deployed to realize the two strategies described by Venuti,

\footnotetext{
${ }^{4}$ Informativity is a term used by Beaugrande \& Dressler (1981: 9), referring to the extent to which the message of the text is (un)known, (un) expected, etc.
} 
generalization and specification, as two methods contrary to each other, are capable of producing different effect in cultural communication with difference in realizing informativity, and hence can be examined to find out how different strategies can be realized through these two types of methods in translating promotional texts for arts. By generalization, we mean the process in which any linguistic element, ranging from a word to a paragraph or even a discourse, is used to convey a meaning that is more general, vaguer or broader into the target text than that in the source text. To be more specific, it refers to the translation method of downgrading the informativity of an expression or a stretch of text by supplying a general term for an expression of specific meaning, or a genus or class is used to replace individuals or refined versions of this genus or class. For instance, a hypernym is used instead of its hyponym to denote a subordinate or a subcategory of a more general class. By specification, we mean the translation method of providing more and detailed information about a given message mentioned in the ST by using a hyponym, adding extra information or give annotation and explanation.

Within the limited space of this paper, the textual analysis will focus on the body texts of two articles. However, before the body texts are analysed, the ST and the TT of the titles and subtitles of the articles about the programmes of the two arts will be compared so as to get a clearer pictures about the actual practice. It should be noted, according to the chief editor of the website of the HKAF, the Chinese versions are the source texts in introducing the Chinese programmes and the English ones are translations, while the source texts on foreign programmes is in English and the translation is in Chinese.

\subsection{How are the Titles and Subtitles Translated?}

As shown in Table 1, the titles and subtitles of the website 
articles used to publicize respectively the Chinese programmes and the Western programmes in the year 2008 are translated differently. (Note: the literal translations, or LT in short, and back translations, or BT in short, are done by the present authors for the convenience of non-Chinese readers.)

Table 1. Translation of the Title and Subtitle of the Arts-publicity Texts

\begin{tabular}{|c|c|c|c|c|}
\hline & & ST & TT & Method \\
\hline \multirow[t]{2}{*}{ Ballet } & title & $\begin{array}{l}\text { Stuttgart Ballet } \\
\text { Onegin }\end{array}$ & $\begin{array}{l}\text { 史图加芭蕾舞团 } \\
\text { 《奥尼金》 } \\
\text { (BT: Stuttgart Ballet } \\
\text { troupe Onegin) }\end{array}$ & transliteration \\
\hline & Subtitle & $\begin{array}{l}\text { Celebrating the } \\
\text { choreographic } \\
\text { genius of John } \\
\text { Cranko with two } \\
\text { spectacular } \\
\text { performances } \\
\text { from his } \\
\text { legendary } \\
\text { repertoire. }\end{array}$ & $\begin{array}{l}\text { 芭蕾舞后 Marcia H } \\
\text { aydée, 编舞大师 W } \\
\text { illiam Forsythe、Jiř } \\
\text { i Kylián、John Neu } \\
\text { meier 恩师 } \\
\text { 廿世纪舞剧大师格 } \\
\text { 兰高八十冥寿 } \\
\text { 艺术节历史呈献 史 } \\
\text { 图加演绎两大经典 } \\
\text { (BT: the eightieth } \\
\text { birthday of Cranko, } \\
\text { the choreographic } \\
\text { genius of 20 } \\
\text { century and the } \\
\text { teacher of Ballet } \\
\text { Queen Marcia } \\
\text { Haydée and of the } \\
\text { choreography } \\
\text { masters William } \\
\text { Forsythe, Jiři Kylián } \\
\text { and John Neumeier } \\
\text { A historical } \\
\text { spectacle of the Art } \\
\text { Festival Stuttgart } \\
\text { performs two } \\
\text { classics }\end{array}$ & specification \\
\hline
\end{tabular}




\begin{tabular}{|c|c|c|c|c|}
\hline \multirow[t]{2}{*}{ Jingju } & title & $\begin{array}{l}\text { 北京京剧院: 京 } \\
\text { 剧丑角宗师萧长 } \\
\text { 华纪念系列 (LT: } \\
\text { Beijing Peking } \\
\text { Opera House: the } \\
\text { Memorial Series } \\
\text { of Xiao } \\
\text { Changhua, the } \\
\text { Great Master of } \\
\text { the Chou Role in } \\
\text { Jungju”) }\end{array}$ & $\begin{array}{l}\text { Beijing Opera } \\
\text { The Master of } \\
\text { Chou: Xiao } \\
\text { Changhua }\end{array}$ & generalization \\
\hline & subtitle & $\begin{array}{l}\text { No Chinese } \\
\text { subtitle }\end{array}$ & $\begin{array}{l}\text { The 130th } \\
\text { anniversary of the } \\
\text { birth of Xiao } \\
\text { Changhua }\end{array}$ & amplification \\
\hline
\end{tabular}

To start with, the comparison of the ST and the TT of the article about the ballet programmes shows that transliteration and specification are resorted to in the rendering of the title and the subtitle from English into Chinese.

To be more specific, the title "Stuttgart Ballet: Onegin" is directly translated with the foreign names transliterated, in which "Stuttgart", the name of the performing troupe, is turned into “史图 加” (Back transliteration: situga) and “Onegin", the name of the performance, into “《奥尼金》” (Back transliteration: onigin). The Subtitle of the ballet programme is amplified with specific information like “芭蕾舞后 Marcia Haydée, 编舞大师 William Forsythe，Jiří Kylián，John Neumeier 恩师”, “艺术节历史呈献” “史 图加演绎” as well as time and age like “世世纪”, “八十冥寿” (see their back translations in Table 1). With such amplified detailed information about the performances, the Chinese translation is apparently more specific than the English subtitle "Celebrating the choreographic genius of John Cranko with two spectacular performances from his legendary repertoire".

What is interesting and noteworthy is that the name of the chief ballet dancer, i.e. Marcia Haydée, and those of the choreography 
masters, i.e. William Forsythe, Jiř́i Kylián and John Neumeier, are not translated at all and all those English names are kept intact in the Chinese subtitle of the article about the ballet programmes by Stuttgart Ballet.

The comparison of the ST and the TT of the article introducing the Jingju programmes, however, shows us a different picture. Generalization, instead of specification, is found deployed in translating the Chinese title into English. With “北京京剧院: 京剧丑 角宗师萧长华纪念系列 (literal translation: Beijing Peking Opera House: the Memorial Series of Xiao Changhua, the Great Master of the Chou Role in Jungju ") turned into "Beijing Opera The Master of Chou: Xiao Changhua", both the name of the performing troupe and the theme of the performance are generalized in the translation to some extent. Firstly, 北京京剧院(LT: Beijing Jingju Theatre), ${ }^{5}$ the performing troupe which is highlighted in the Chinese title, is replaced with "Beijing Opera", the name of the theatre, in the English version, and as a result, the theatre rather than the performing troupe is topicalized in the translation. Secondly, the theme has been generalized in the English TT by turning "the Great Master of the Chou role in Jingju" into "The Master of Chou".

Moreover, in terms of informativity, opera is a term more general in meaning than Jingju and can be roughly taken as the super-ordinate or hypernym of Jingju, considering the fact opera refers to a theatrical presentation in which a dramatic performance is set to music and Jingju might be taken as kind of such presentation of dramatic performance. However, it should be noted that jingju differ greatly from Western opera as it is a comprehensive form of performing arts that combines vocal performance, mime, dance,

\footnotetext{
${ }^{5}$ There is no standard English for the name of the troupe yet, and it is referred to by the HKAF as The Peking Opera House, though on the Chinese mainland it is usually referred to as "Beijing Peking Opera Theatre", as at the Chinese Culture Net (accessible at http://www.chinaculture.org/gb/en_artists/2003-09/24/content_ 40514.htm.
} 
music and acrobatics, and its various roles distinguish from one another with the unique colourful make-ups of its actors who dress up in various beautiful costumes in the performances. Using “Beijing Opera" to refer to “京剧” rather than transliterating it as "Jingju", the most achieved Chinese traditional form of theatre is thus assimilated as "opera like La Traviata or Camen" (Zhao 2007), though in this way, the translation of the first part of the title becomes easily accessible to the English reader. As for the subtitle, the TT amplifies a subtitle "The $130^{\text {th }}$ anniversary of the birth of Xiao Changhua", which is absent from the original, and it supplements some of the missed information in the translated title to some extent. Yet, the English readers still have no idea about the performing troupe being the most renowned Beijing Peking Opera House, the programmes being a series and Xiao being the great master instead of master of Chou.

The theme of the Chinese performance is different in the English translation and the Chinese original in terms of informativity, as the English title is more general than the Chinese original. The Chinese title “京剧丑角宗师萧长华纪念系列” (LT: the Memorial Series of Xiao Changhua, the Great Master of the Chou Role in Jungju) suggests that the series of performances are meant to show homage to Master Xiao Changhua, and therefore the performances in a series as tributes to the Master is emphasized. The English version chooses to stress the artist, Xiao Changhua, as the master of Chou, so the individual rather than the performances has been topicalized. The translation is thus more general in the sense that it conveys less complicate information than that in the original.

\subsection{How are the Body Texts Translated?}

\subsubsection{E-C Translation of the Text about Ballet Programme}

Comparing the body texts of the two versions in question, we 
find that the English introduction to the foreign Ballet programmes is made more specific when translated into Chinese. A detailed analysis of the two versions shows that the method of specification is realized both by adding some detail information as well as rendering summarizing expressions into more specific words in the Chinese version. The first paragraph in the ST and TT is such an example (the underlined is added by the present author to indicate omissions in the ST and additions in the TT; the bolded added to indicate the general expressions in the ST and the specific in the TT):

(1) ST:John Cranko's narrative vision and grand-scale choreography inspired many dance greats - Marcia Haydée, William Forsythe and John Neumeier, to name but a few. A revolutionary in the classic ballet form, he is widely revered as a dance 'master of masters'.

$\mathrm{TT}$ : 芭蕾舞剧大师约翰. 格兰高, 领导史图加芭蕾舞团十 二年, 一手成就史图加国际顶级舞团的地位, 创作多出 经典舞剧, 被誉为廿世纪舞剧大师之一, 更为舞坛带来 了芭蕾天后玛茜 - 海蒂、男星埃贡 -马德森, 编舞大师 威廉 - 科西、约翰 - 纽迈亚、尤利 - 季利安, 都在他鼓 励下踏出编舞的第一步。

The first paragraph of ST and that of the TT are roughly corresponding to each other, both of which give introduction to John Cranko, of whose birth the ballet programmes are intended to celebrate. However, the information the Chinese translation is more specific than that in the English original. First of all, the Chinese translation adds detailed information about the relation between John Cranko, i.e. the choreographer, and Stuttgart Ballet, i.e. the performing troupe at the beginning of the Chinese translation, which goes “[格兰高]领导史图加芭蕾舞团十二年, 一手成就史图加国际顶 
级舞团的地位, 创作多出经典舞剧”(BT: Cranko, leading Stuttgart Ballet for twelve years and turning Stuttgart into one of the best dance troupes in the world, created several classical dance plays). With information added about his great achievement in ballet, the Chinese version is more likely to bring the Chinese audience to adore John Cranko than a literal translation of the two nominal phrases "narrative vision and grand-scale choreography" in the original into “[格兰高]叙事性表现手法和宏大舞剧的编排技巧”, as which would sound neither specifically important or appealing to the Chinese reader. Then "inspired", the verbal predicate after those two nominal phrases, is paraphrased and rendered into two verbal clauses in Chinese, i.e. “为舞坛带来了...” (BT: [He has] brought into the dance world ...) and “...在他鼓励下踏出编舞的第一步” (BT: [They were] are all encouraged by him to take the first step into choreography). Additionally, the Chinese translation contains more names of "dance greats" than in the original, and their titles are added to their names. Specifically, the Chinese version, instead of listing names of Marcia Haydée, William Forsythe and John Neumeier and using the summarizing phrase "to name but a few", the Chinese separates those big names in ballet into two groups, namely dancers and choreographers, and adds one to each group, i.e. “男星埃贡 -马德森” (BT: male star Icon Madsen) and “编舞大师... 尤利 - 季利安” (BT: choreographer ... Jirl Kylian). In this way, the Chinese version contains more information and becomes more specific than the source English text. With amplification of such big names, the Chinese introduction to the ballet programmes is even more informative and makes the programme more attractive. What is more, the statement "he is widely revered as a dance "master of masters" “ is rendered into “被誉为廿世纪舞剧大师之一” (BT: [he] is revered as one of the master of dance play choreography of the twentieth century). With time “廿世纪” (BT: the twentieth century) added and “dance” turned into “舞剧大师” (BT: the master of dance play choreography), the translation again contains more specific 
information than the English original .

While in example (1) adding details is found to be means of specifying the choreographer's achievement and contribution, example (2) below shows us other ways of specification in the Chinese translation.

(2) ST: "[Cranko] tells the story so fluently that the individ ual steps don't seem to exist: They dissolve in feeling." Boston Globe TT:

《奥尼金》「格兰高的《奥尼金》如水银泻地, 一气呵 成, 分不清个别舞步, 只因全已融化在情感中」《波士顿 地球报》

In example (2), a comment on the general style of choreographer is quoted in ST. However, in the TT, the comment is attributed specifically to Onegin, one ballet work choreographed by Cranko and is highlighted in the website article. Another instance of specification is the rendering of "[Cranko] tells the story fluently" into “格兰高的 《奥尼金》如水银泻地, 一气呵成” (BT: [Cranko's Onegin is] like crystal water flowing limpidly on the ground, accomplishing all the moves [so smoothly] as if taking one breath) The Chinese version with two figurative expressions succeeds in conveying the sense of "fluently" into two vivid phrases describing the imaginary picture of the dance movements. The appraisal (Martin 2003: 23) in the original quote could be translated directly into “叙事流畅” (BT: narrate the story smoothly) if no effort was attempted in producing such a picturesque image as in the TT above. Obviously the description of the style is strengthened in terms of appraisal in the Chinese version and made the image livelier with those two four-character-patterned Chinese expressions of parallel structure.

(3) ST: ..., Onegin is an enduring tale of a broken heart, 
a deadly duel and passionate revenge. Rejected in her youth by the arrogant aristocrat Onegin, Tatiana buries her love and grows gracefully into womanhood. Many years later when Onegin realises his mistake and declares his love, the circumstances have changed, and Tatiana must painfully refuse his advances. The final pas de deux, in which Tatiana sends Onegin away, is a sensational tussle between love and moral duty and one of the most heart-wrenching scenes in all ballet. Onegin is set to Tchaikovsky"s music, arranged and orchestrated by Kurt-Heinz Stolze.

$\mathrm{TT}$ ：当年玩世不恭的奥尼金拒绝纯真少女泰坦妮亚的 爱, 多年后再遇, 才知真爱谁属, 奈何心上人已作他人 妇。格兰高选取了普希金原著中一系列令人难忘的场 面: 花园邂逅、闺中订情、双雄决剑与莺然回首, 手工 精细的服装与格局宏大的布景, 配以令人屏息的高难度 芭蕾技巧, 细致地刻划人物的内心世界, 描绘感情的跌 宕, 两场荡气回肠的双人舞更列为舞坛经典。1965 年首 演时, 担演泰坦妮亚的玛茜. 海蒂, 光芒四射, 是最令 人着迷的芭蕾角色之二。

The opening sentence in the English introduction to the ballet programme, "(Onegin) is an enduring tale of a broken heart, a deadly duel and passionate revenge", is a thesis statement which summarizes the theme of the play. Notably, such a general statement is omitted in the translation, and the Chinese version goes directly into narrating the story in time sequence without any thesis statement at the beginning. However, in the Chinese translation, a lot of information related to the dance programme has been added, including the costume of the dancers, i.e. “手工精细的服装” (BT: costumes of exquisite craftsmanship), setting of the stage “格局宏大 的布景” (BT: grand and splendid setting) and skills of the performers “配以令人屏息的高难度芭蕾技巧” (BT: accompanying 
with breath-taking superb ballet skills) and the key dancer Marcia"s charming performance in 1965, “1965 年首演时，担演泰坦妮亚的玛 茜. 海蒂, 光芒四射, 是最令人着迷的芭蕾角色之一” (BT: In its debut in 1965, Marcia Haydée, featuring Tatiana, shining and radiating, was one of the most attractive ballet role). Adding such details makes the Chinese version more informative than the English original and thus might build a closer relationship between the audience and the performance than the original does, as the information is related to the upcoming performance regarding the costume, the setting of the stage, the performers" skills and the chief actress' success in previous performing experience, and all is quite specific compared to the general information in the ST.

\subsubsection{C-E Translation of the Text about Jingju Programmes}

While specification is found dominantly used in translating the English article on the ballet programmes into Chinese, generalization is resorted to in rendering the Chinese introduction to the Jingju programmes into English. At a glance, the most impressive difference between the English translation and the Chinese original is the length, as the TT is much shorter and is only half the length of the ST (see the Appendix attached). A more careful comparison finds that the English version contains much less information, and generalization is the dominant method used in rendering the introduction.

First of all, omission is the most obvious way of generalization in the Chinese to English translation of the texts about the Jingju programme in question. The most apparent omission is found in the synopses. In the Chinese version, each of the four plays to be staged is give a synopsis, but all of them are omitted in the English version. In addition, the detailed information about both the artistic form and the artist is also omitted, and the four paragraphs with 11 lines before the synopses in the ST are reduced into two paragraphs in the 
translation, each in less than 3 lines. In the following paragraphs, omission is further elaborated with some examples.

In the Chinese original, the first paragraph introducing the role of Chou in the Chinese theatrical performances, starts with a description of his “trade mark” “鼻梁上的豆腐块, 或大或小, 可圆 可方, 是戏曲中丑行, 也称「小花脸」的标记” (LT: a patch of white paint like a piece of bean curd on the bridge of the nose, big or small, round or square, is the trade mark of the role of Chou, also known as 'small painted face' in the traditional theatre.), then followed by its significance in the Chinese theatre, “戏行有云「无丑不成戏」” (LT: The theatrical profession has such a saying "no Chou, no play is possible'), and the wide social spectrum Chou can play across, “丑 行戏路纵横, 上自天子诸候, 下到流讯恶㾂, 都入小花脸行当” (LT: The role of Chou is capable of playing a great variety of characters, ranging up from emperors and peers, down to ruffians and gangsters, all of whom can be featured by the role of the small painted face). However, the English version only keeps one of the three aspects about Chou, and that is the description of the mark: A patch of white paint, like bean curd on the bridge of the nose, is the trade mark of the Chou. The importance of the role of Chou in Chinese traditional operas and the fact that the role can play a wide range of characters is totally omitted in the translation. Even the image of the Chou in the English translation appears to be vaguer than that in the original, since the indication of the possible shapes of the "trade mark" (或大 或小, 可圆可方) (LT: sometimes big and sometimes small, sometimes round and sometimes square) is not translated, which also makes the description more general.

The third paragraph of the Chinese version, which gives quite detailed information about Xiao Changhua, the artist that the Jingju programmes are to pay tribute to, is also reduced into one sentence in the English version, which simply says "Of all the Chou actors, the greatest was Master Xiao Changhua". All the other aspects of the Master, such as his significance as a Chou actor (在这不可或缺的 
戏曲行当中，有这一位不可或缺的人物) (LT: Among people who acting as such a indispensible role in the theatrical plays, there is one such indispensible figure), his artistic achievement (七十多年的 艺术生命中，他不仅创造了二百多个脍采人口的丑角形象：蒋干、汤 勤、杨衙内、张别古、崇公道等等) (LT: In his seventy years' art life, he not only created over two hundred popular images of the role of Chou that are on everyone's lips, including Jiang Gan, Tang Qin, Yang Yanei, Zhang Biegu, Chong Gongdao, etc.), omission also goes to his contribution to the arts (亦致力整理传统老戏和编创新剧, 丰富了京剧的内容; 更重要的是积极培育戏曲人才, 先后担任对京剧 艺术持续发展影响深远的富连成科班总教习, 其后任中国戏曲学校校 长, 为京剧栽培不少人才) (LT: [he] also enriched the Jingju repertory with his devotion in choreographing new plays while collecting and rewriting traditional ones; more significantly, he engaged himself in training new players for the Chinese theatre and succeeded in nurturing a great many talented actors during the time he served first as the head of the influential Fucheng Professional Jingju Training Troupe and then the headmaster of the Chinese Theatre School).

Moreover, though the Chinese original gives not only the titles of all the plays to be staged in the Festival but also the appealing features of the plays, not a bit of any information about the specific plays can be found in the English version. In addition, the stellar cast, emphasized in he fourth paragraph in the Chinese original which is also absent in the TT, though the conative expression (绝对 不容错过!) (LT: [The performance is] absolutely not affordable to be missed!) in the ST is kept in the translation (don't miss the chance).

As translation, the English version does convey part of the information given in the Chinese original, partially with summarizing words and partially from direct translation. Attention is given particularly to the summarizing words here as they are found frequently used to generalize the detailed narration and description of the Chinese version in translation. Here are two of 
such examples. The first one is that the English version uses the summarizing words "(present) four works closely associated with his names" to generalize the information of the plays in the Chinese version which says “演出两个萧先生的首本丑行戏: 《乌盆记》、《审 头刺汤》和分别于两晚演出不同折子的《龙潭鲍骆》, 以及尽显花面老 旦功架的唱功戏《赤桑镇》” (LT: [The troupe] will present two of his most renowned repertories The Story of Back Basin and Testing heads and Assassinating the rascal ${ }^{6}$, and will stage different $\mathrm{Zhezi}^{7}$ of the play Revenge and Reconcile at Dragon Pond in two nights, and also Scarlet Berry Town, ${ }^{8}$ the play that can best display the art of singing of a performer featuring an old female painted-face role.) The word "works" is a hypernym, a term that includes writings of any kinds or anything that has been produced or accomplished through the effort, activity, or agency of a person or thing. So broad and vague, it is a much more general word than the various Chinese terms used in the original article, for instance, “首本丑行戏” (LT: his most renowned repertories), “折子”(LT: highlights of a play), “唱功 戏”(LT: the play best displaying the art of singing of a performer), all of which are hyponyms of the word "play", a subcategory word under the word "works". The message in the translation is further generalized with "some superb Beijing Opera" in the conative sentence at the end of the TT, as the word "some" is even vaguer than the numeral word "four" and "Beijing Opera" is also far from specific as a referent compared with the original terms.

\section{Preliminary Findings}

From the analysis in the pilot study, it is found that opposite

\footnotetext{
${ }^{6}$ More literally, it is Testing heads and Assassinating Tang. Though "Tang" is the surname of the rascal that was assassinated in the play, "the rascal" instead of "Tang" is used in the translation, probably for convenience of English readers.

${ }^{7}$ Zhezi is a term used in Jingju referring to the highlight acts of a play.

${ }^{8}$ It is often translated as Righteousness above Family Loyalty according to the theme of the play.
} 
translation methods are used in translating the two texts, i.e. generalization in translation from Chinese to English, while specification used in translating from English to Chinese. The two methods respectively result in different styles of the translated texts, with the English translation being domesticated and the Chinese translated text foreignized. This is further elaborated in the following sections.

\subsection{Specification: Foreignization}

To start with, the title of the article about the ballet programmes is literally translated, which is quite different from the way the title of the article about the Chinese programmes is rendered (see 3.2). The subtitle, however, contains more detailed information in the Chinese version than the English original, as time and the performing troupe, which is not found in the original, is supplied in the Chinese subtitle. Even the names of the "dance greats" inspired by John Cranko, the choreographic genius are listed in English with their titles in the Chinese subtitle, which results in a hybrid of Chinese and English in the translation.

Then in the body text, except the general statements in the ST omitted in the translation, most of the sentences are rendered into more specific expressions that introduce the artistic director, the ballet troupe and the ballet in great details. So addition is quite frequently found, which contributes significantly to specify relevant information about the programmes in the Chinese translated introduction.

The Chinese version is thus a translation resulting from foreignization with transliteration of proper names, additions of English names, and specification of many aspects of detailed information. In fact, the foreignness is upgraded to a greatest possible extent with those English names kept intact in the Chinese translation. The effort of highlighting the foreign identity of the 
ballet programmes can also be evidently found in specifying the introduction with detailed information added or literally translated. Both the added and the literally translated information enhance the foreignness in the translation consequently. A very possible assumption hold by the translator or the editor might be that the Chinese reader will not find the translation difficult to understand or they will be willing to process the foreignness contained in the translation.

To sum up, foreignizing the English texts about the Western programmes involves methods of specification and transliteration. The effect of such rendering is that the foreignization strategy exerts "an ethno-deviant pressure on [target-language cultural] values to register the linguistic and cultural difference of the foreign text" and succeeds in "sending the reader abroad" (Venuti 1995: 20).

\subsection{Generalization: Domestication}

In analyzing the Chinese to English translation, we got a quite different picture. We find generalization is dominant in translating texts about the Chinese programmes. First, the titles and the subtitles of the Chinese programmes are generalized, as the example of turning “京剧” into “Beijing Opera”.

Second, generalization is also found prevailing in the translation of the body text about Jingju programmes from Chinese to English. The rendering of specific information of the ST into the TT results unavoidably in domestication. For example, with omission, the distinguish characteristics of the role of Chou in Jingju introduced in the Chinese version become vague and general in the English translation, in which the description of his "trade mark" is largely omitted. The artistic achievement and contribution of Xiao Changhua, the Great Master of Chou, is also omitted, which reduces the information in the English translation greatly. So is the omission of the synopsis of the plays to be staged. As a result, the information 
about the Chinese traditional theatre becomes much more general in the English translation.

The case analysis of the Jingju programme shows that, the English translation is transparent and fluent with such instances of generalization and omission. The peculiarities of Jingju is actually largely erased and translated into cultural elements that comply with English wherever possible. The translated text about the Chinese programme thus results in much less informative English, and the foreign identity of Jingju as a Chinese traditional theatre has been downgraded together with the erasing of the foreignness of the Chinese texts. In this way, less exotic information is conveyed into the TT and the translation becomes transparent. The aesthetic and cultural otherness (Venuti 1992: 6) of the Chinese original is suppressed and the dominance of the target culture is realized with the method of generalization in translation, which produces a transparent, fluent, "invisible" style in translation and consequently the foreignness of the target texts is minimized.

\section{Further Examination: Enlarging the Data}

Before we move on, one might argue that the preliminary findings are based on a small scale of examples and the translations examined above could be special cases that happen to use predominantly generalization and specification respectively for texts for Jingju and ballet programmes in HKAF in that particular year. We find that the same tendency can be also found in translations of texts about programmes of the two artistic forms in HKAF in other years. For instance, in the translations of texts about Jingju and Ballet programmes in the upcoming $39^{\text {th }}$ Hong Kong Arts Festival to be hold in the year 2011, generalization and specification can be found in both the titles and subtitles in the translation. The analysis finds that both the title and subtitle of the Chinese programme have 
been generalized and less specific description is provided in the translation, while transliteration is used in rendering the title of the text on the Western programme and specification used in its subtitle, as shown in Table 2 (LT stands for literal translation, and BT stands for back translation; CST stands for Chinese source text, and ETT stands for English target text).

Table 2. Methods Used in Translations on Jingju and Ballet Programmes of 2011 HKAF

\begin{tabular}{|c|c|c|c|c|c|}
\hline & & ST & $\begin{array}{c}\text { LT of CST OR } \\
\text { BT of ETT }\end{array}$ & TT & Method \\
\hline \multirow[t]{2}{*}{$\begin{array}{c}\text { Jingju } \\
\text { (Beijing } \\
\text { Opera) }\end{array}$} & title & $\begin{array}{l}\text { 铜锤架子 虎 } \\
\text { 啸龙吟 } \\
\text { 京剧花脸流派 } \\
\text { 经典展演 }\end{array}$ & $\begin{array}{l}\text { Classical } \\
\text { exhibiting } \\
\text { plays with } \\
\text { Jingju's } \\
\text { painted-face } \\
\text { roles of } \\
\text { Tongchui and } \\
\text { Jiazi, who } \\
\text { sing like tigers } \\
\text { growling and } \\
\text { dragons } \\
\text { crooning }\end{array}$ & $\begin{array}{l}\text { Beijing } \\
\text { Opera } \\
\text { The } \\
\text { Painted } \\
\text { Faces }\end{array}$ & generalization \\
\hline & subtitle & $\begin{array}{l}\text { 两大京剧花脸 } \\
\text { 四出净角名剧 } \\
\text { 尽显行当功架 }\end{array}$ & $\begin{array}{l}\text { Two great } \\
\text { players of } \\
\text { painted faces } \\
\text { in Jingju: } \\
\text { performing } \\
\text { four famous } \\
\text { Jingiiao plays } \\
\text { which fully } \\
\text { display their } \\
\text { marveling } \\
\text { singing and } \\
\text { martial arts }\end{array}$ & $\begin{array}{l}\text { Marvel at } \\
\text { the makeup, } \\
\text { martial arts } \\
\text { and singing } \\
\text { of } \\
\text { thunderous } \\
\text { power }\end{array}$ & generalization \\
\hline Ballet & title & $\begin{array}{l}\text { New York } \\
\text { City Ballet }\end{array}$ & $\begin{array}{l}\text { New York } \\
\text { City Ballet } \\
\text { Troupe) }\end{array}$ & $\begin{array}{l}\text { 纽约市芭 } \\
\text { 蕾舞团 }\end{array}$ & transliteration \\
\hline
\end{tabular}




\begin{tabular}{|c|c|c|c|c|}
\hline & $\mathrm{ST}$ & $\begin{array}{c}\text { LT of CST OR } \\
\text { BT of ETT }\end{array}$ & $\mathrm{TT}$ & Method \\
\hline Subtitle & $\begin{array}{l}\text { A celebration } \\
\text { of the 20th } \\
\text { century's } \\
\text { great } \\
\text { choreograph - } \\
\text { ers Balanchine } \\
\text { and Robbins } \\
\text { Exciting new } \\
\text { choreography } \\
\text { from the } \\
\text { twenty-first } \\
\text { century - } \\
\text { Alexei } \\
\text { Ratmansky }\end{array}$ & $\begin{array}{l}\text { BT: With all } \\
\text { its players } \\
\text { visiting Hong } \\
\text { Kong for the } \\
\text { first time, the } \\
\text { Troupe brings } \\
\text { seven of its } \\
\text { greatest } \\
\text { works, } \\
\text { including } \\
\text { West Side } \\
\text { Story Suite } \\
\text { and other } \\
\text { classics by } \\
\text { Balanchine, } \\
\text { which forms } \\
\text { an exhibit of } \\
\text { its long and } \\
\text { profound } \\
\text { tradition and } \\
\text { profusion of } \\
\text { dancing }\end{array}$ & $\begin{array}{l}\text { 历史性访港 } \\
\text { 舞团倾团 } \\
\text { 而出 } \\
\text { 七部镇团作 } \\
\text { 包括《梦断 } \\
\text { 城西组 } \\
\text { 曲》、巴兰 } \\
\text { 钦经典 } \\
\text { 大显深厚 } \\
\text { 传统与缤 } \\
\text { 纷舞技 }\end{array}$ & specification \\
\hline
\end{tabular}

To show generalization is a long-term trend in the translations of the articles promoting Chinese opera in HKAF, we have analyzed the titles of programmes of Jingju (Beijing opera) and Yueju ${ }^{9}$ (Cantonese opera) in HKAF before 2008, mainly from the year 2004 to 2007 , and summed up the methods used in the translations in Table 3.

\footnotetext{
${ }^{9}$ The major reason of extending the data to include titles of texts introducing Yueju (Cantonese opera) programmes is for the fact that Cantonese is the local dialect in Hong Kong and Yueju is one of the most often staged theatrical forms in HKAF andhas been traditionally enjoyed by many people speaking Cantonese.
} 
Table 3. Methods in Translating Titles of Chinese Opera Programmes in HKAF (2004-2007)

\begin{tabular}{|c|c|c|c|c|c|}
\hline year & No. & ST Title & $\begin{array}{c}\text { LT of C ST OR } \\
\text { BT of E TT }\end{array}$ & TT & Method \\
\hline \multirow[t]{3}{*}{2004} & $\begin{array}{c}2004- \\
\text { O1 }\end{array}$ & $\begin{array}{l}\text { 中国京剧院 } \\
\text { 及北京京剧 } \\
\text { 院 一 程派 } \\
\text { 艺术一百年 }\end{array}$ & $\begin{array}{l}\text { China National } \\
\text { Peking Opera } \\
\text { House and Beijing } \\
\text { Peking Opera } \\
\text { House - The art of } \\
\text { Cheng School: one } \\
\text { hundred years old }\end{array}$ & $\begin{array}{l}\text { Beijing Opera - } \\
\text { The Art of } \\
\text { Cheng Yanqiu: } \\
\text { 100th } \\
\text { Anniversary }\end{array}$ & generalization \\
\hline & $\begin{array}{c}2004- \\
\mathrm{O} 2\end{array}$ & $\begin{array}{l}\text { 北京京剧院 } \\
\text { 一 生行七代 } \\
\text { 话谭门 }\end{array}$ & $\begin{array}{l}\text { Beijing Peking } \\
\text { Opera House - } \\
\text { Seven generations in } \\
\text { Tan family playing } \\
\text { the role of Sheng }\end{array}$ & $\begin{array}{l}\text { Beijing Opera - } \\
\text { Two Centuries } \\
\text { of the Legendary } \\
\text { Tan Family }\end{array}$ & generalization \\
\hline & $\begin{array}{c}2004- \\
\text { O3 }\end{array}$ & $\begin{array}{l}\text { 粤剧 一 } \\
\text { 龙凤 大时代 }\end{array}$ & $\begin{array}{l}\text { Cantonese Opera- } \\
\text { The great dragon } \\
\text { and phoenix, the } \\
\text { great era }\end{array}$ & $\begin{array}{l}\text { The Great } \\
\text { Dragon and } \\
\text { Phoenix Era of } \\
\text { Cantonese Opera }\end{array}$ & generalization \\
\hline 2005 & $\begin{array}{c}2005- \\
\text { O1 }\end{array}$ & $\begin{array}{l}\text { 粤剧 一 诗 } \\
\text { 情缘系唐涤 } \\
\text { 生 }\end{array}$ & $\begin{array}{l}\text { Cantonese Opera - } \\
\text { the poetic emotion } \\
\text { and destiny } \\
\text { connection featured } \\
\text { by Tong Tik-sang }\end{array}$ & $\begin{array}{l}\text { Cantonese opera - } \\
\text { Masterpieces by } \\
\text { Tong Tik- sang }\end{array}$ & generalization \\
\hline \multirow[t]{2}{*}{2006} & $\begin{array}{c}2006- \\
\text { O1 }\end{array}$ & $\begin{array}{l}\text { 京剧 一 女 } \\
\text { 生男旦 }\end{array}$ & $\begin{array}{l}\text { Peking Opera - } \\
\text { females playing the } \\
\text { role of males and } \\
\text { males the role of } \\
\text { females }\end{array}$ & $\begin{array}{l}\text { The Artistry of } \\
\text { Gender } \\
\text { Switching in } \\
\text { Beijing Opera }\end{array}$ & generalization \\
\hline & $\begin{array}{c}2006- \\
\mathrm{O} 2\end{array}$ & $\begin{array}{l}\text { 粤剧 一 虚 } \\
\text { 龙假凤争挂 } \\
\text { 帅 }\end{array}$ & $\begin{array}{l}\text { Cantonese Opera- } \\
\text { a simulated male } \\
\text { and a disguised } \\
\text { female competing } \\
\text { to be the } \\
\text { commander in chief }\end{array}$ & $\begin{array}{l}\text { The Artistry of } \\
\text { Gender } \\
\text { Switching in } \\
\text { Cantonese Opera }\end{array}$ & generalization \\
\hline 2007 & $\begin{array}{c}2007- \\
\text { O1 }\end{array}$ & $\begin{array}{l}\text { 奥剧 一 } \\
\text { 《盗御马》 }\end{array}$ & $\begin{array}{l}\text { Cantonese Opera- } \\
\text { Stealing the } \\
\text { Imperial Horse }\end{array}$ & $\begin{array}{l}\text { Cantonese Opera } \\
\text { - Stealing the } \\
\text { Imperial Horse }\end{array}$ & $\begin{array}{c}\text { Literal } \\
\text { translation }\end{array}$ \\
\hline
\end{tabular}


Generalization is found dominantly used in translating the titles of Jingju and Yueju programmes staged in HKAF during the years from 2004 to 2007. To be more specific, among the seven Chinese titles of texts promoting Jingju and Yueju programmes, $85 \%$ (i.e. 6 out of 7) are generalized in translation, and only the one in 2007 is literally translated. Observe Table 3 closely, we can see that detailed information about the performing troupes are missing in the translation (e.g. TT of 2004-O1), or replaced with the name of the artistic form itself (e.g. TT of 2004-O1 and 2004-O2), even though such information can be quite important for the potential audience in their decision to go to the performance or not for the obvious reason that performing troupes matter greatly in the quality of the performance, and troupes like China National Perking Opera House and Beijing Peking Opera House have always been troupes with great appeal to Jingju audience in China as they top the country. Moreover, super-ordinate words are found frequently used in the English translated titles and replacing the detailed information or more specific descriptions in the original title in Chinese, for instance, "two centuries" instead of the original “七代” (LT: seven generations) in 2004-O2, “masterpieces” instead of “诗情缘系” (LT: the poetic emotion and destiny connection featured) in 2005-O1, and “The Artistry of Gender Switching” instead of “女生男旦” (LT: females playing the role of males and males the role of females) in 2006-O1 and instead of “虚龙假凤争挂帅” (LT: a simulated male and a disguised female competing to be the commander in chief). Consequently some information, often significant to the potential audience's decision, is lost in the translated title.

Compared with the trend of generalization in English translations of titles on Chinese programmes, analysis of the Chinese translated titles on ballet programmes by Western troupes gives us a different picture. It should be noted there was no ballet performance staged in HKAF in the year 2007, and as a result titles of six ballet programmes are examined. Among them, transliteration is found to 
140 Foreignized or Domesticated

be the most frequently adopted method in the translation, as shown in Table 4.

Table 4. Methods in Translating Titles of Ballet Programmes in HKAF (2004-2006)

\begin{tabular}{|c|c|c|c|c|c|}
\hline \multirow[t]{3}{*}{2004} & $\begin{array}{c}\text { 2004- } \\
\text { B1 }\end{array}$ & Zurich Ballet & Zurich Ballet & $\begin{array}{c}\text { 苏黎世芭蕾 } \\
\text { 舞团 }\end{array}$ & Transliteration \\
\hline & $\begin{array}{c}2004- \\
\text { B2 }\end{array}$ & $\begin{array}{c}\text { Les Ballets C. de } \\
\text { la B. }\end{array}$ & Ballet $\mathrm{C}$ of $\mathrm{B}$ & 芭蕾 B 之 C & $\begin{array}{l}\text { Transliteration + } \\
\text { literal translation }\end{array}$ \\
\hline & $\begin{array}{c}2004- \\
\text { B3 }\end{array}$ & B.O.B. ${ }^{*}$ & B.O.B. * & 《B.O.B. $*\rangle$ & Not translated \\
\hline 2005 & $\begin{array}{l}2005- \\
\text { B1 }\end{array}$ & $\begin{array}{l}\text { Béjart Ballet } \\
\text { Lausanne }\end{array}$ & $\begin{array}{c}\text { Lausanne } \\
\text { Bejart Ballet }\end{array}$ & $\begin{array}{c}\text { 洛桑贝撒芭 } \\
\text { 蕾舞才 }\end{array}$ & Transliteration \\
\hline \multirow[t]{2}{*}{2006} & $\begin{array}{c}\text { 2006- } \\
\text { B1 }\end{array}$ & $\begin{array}{c}\text { Birmingham } \\
\text { Royal Ballet - } \\
\text { Beauty and the } \\
\text { Beast }\end{array}$ & $\begin{array}{c}\text { Birmingham } \\
\text { Royal Ballet - } \\
\text { Beauty and the } \\
\text { Beast }\end{array}$ & $\begin{array}{c}\text { 伯明翰皇家芭 } \\
\text { 蕾舞团 一《美 } \\
\text { 女与野兽》 }\end{array}$ & $\begin{array}{c}\text { Transliteration + } \\
\text { literal } \\
\text { translation }\end{array}$ \\
\hline & $\begin{array}{l}2006- \\
\text { B2 }\end{array}$ & $\begin{array}{c}\text { Eva Yerbabuena } \\
\text { Ballet Flamenco - } \\
E V A\end{array}$ & $\begin{array}{c}\text { Eva Yerbabuena } \\
\text { Flamenco } \\
\text { Dance Troupe - } \\
\text { EVA }\end{array}$ & $\begin{array}{l}\text { 伊娃 耶珀贝恩 } \\
\text { 娜佛兰明高舞 } \\
\text { 蹈团 - 《伊娃》 }\end{array}$ & Transliteration \\
\hline
\end{tabular}

Examine the English titles and their Chinese translations closely, we can see transliteration is found in rendering not only name of the artistic form itself (i.e. turning "ballet” into “芭蕾” [balei], as in 2004-B2) but all the proper names of foreign origins, including the names of the performing troupes (e.g. turning “Zurich" into “苏黎 世” [suyishi] in 2004-B1, "Lausanne” into “洛桑” [Luosan] in 2005B1, “Birmingham” into “伯明翰” [bominghan] in 2006-B1, “Eva Yerbabuena” into “伊娃·耶珀贝恩娜” [Yiwa Yebobeiena] in 2006B2) and the name of the performance to be staged (e.g. "EVA" into 《伊娃》[yiwa] in 2006-B2). More strikingly, there are cases in which even some English letters are kept unchanged when the English titles are translated into Chinese translations, as in 2004-B2 which keeps "B" and "C" in its Chinese translated version and in 2004-B3 which uses the original title B.O.B. in the title of the Chinese text. 
Literal translation is deployed from time to time. For instance, the English names of the performance, "Beauty and the Beast", is turned literally into “《美女与野兽》” in Chinese in 2006-B1, while the troupe name "Les Ballets C. de la B” in rendered into “芭蕾 B 之 C” in Chinese which is a combination of literal translation and transliteration.

From the analysis of the enlarged sample, we find, much in line with our preliminary findings, different translation methods are deployed in translating texts about programmes of Chinese origin and of Western origin. On the one hand, generalization is dominantly used in translating titles of texts introducing Jingju and Yueju for English audience, and as a result the English translations leave out the peculiarities of the Chinese programmes and become less informative. With aesthetic and cultural otherness suppressed and less exotic information conveyed, the translations become transparent and fulfil the strategy of domestication. On the other hand, transliteration and literal translation are found deployed in handling the titles of ballet programmes from 2004-2006, while specification in the subtitle in 2010, the Chinese translations keep the foreignness or even highlights the Otherness of the foreign programmes, which consequently leads to foreignization.

\section{Discussion: Translation Strategies and Cultural Inequality}

Both the analysis of sample data in our pilot study and the examination of the enlarged data suggest that, as a result of the use of different translation methods, different translation strategies are achieved in rendering texts introducing programmes of Chinese origin and those of Western one, which virtually leads to changes in the translations in terms of informativity. With domestication used in Chinese texts about Chinese programmes into English, the 
Chinese art forms have been assimilated and losing their peculiarities; with foreignization adopted in Chinese translations of English texts about Western programmes like those of ballet, the Otherness is kept in the translated texts and imposes Western cultural values on a Chinese readership.

Why are different strategies deployed in translating the same type of texts which are cultural loaded? According to the information from our interview of Daisy Chou, the chief editor of the website texts of the HKAF, the context of situation of the website articles in question can be summed up in one sentence, and that is "the articles are meant to give information about the programmes to those who know about and are also interested in a given artistic form to buy tickets". From this, we know that the function of the texts is to inform the potential audience, but the ultimate goal is to sell tickets. In other words, by giving information, the translations as well as the original texts are intended to achieve the commercial goal of selling tickets. According to Daisy Chou, the translations are target-reader oriented, and she emphasized that the publicity-related texts only targeted at the group of people who had already got some knowledge about the given artistic form. From the translation, we got the impression that the Chinese readers know much more about Ballet than the English speaking readers know about JingJu, since "the strategies employed by translators reflect the context in which texts are produced" (Bassnett \& Trivedi 1999: 6). In other words, the domestication strategy is used in translating Chinese into English about the Chinese programmes so as not to exceed the English readers' state of knowledge, while on the other hand, foreignization is employed in translating the texts about the ballet programmes as the target Chinese readers are generally more familiar with the artistic form originated from the West.

The analysis of those publicity-related texts and the titles of the programmes also suggests that the choice of strategies largely depends on the translator and the editor's assumptions about the 
knowledge of the target readers about the arts of the source cultures. To guarantee the successful publicity of a given programme, such assumptions should reflect the real state of the potential reader to the greatest possible extent. As an annual international festival, HKAF targets at the travellers from abroad and the Chinese Mainland as well as the Hong Kong locals, including both the Chinese and the expatriate population in Hong Kong. In this case, the readers of the Chinese translations of the English texts about the Western programmes are mostly likely the local Hong Kong Chinese who are very familiar with Western cultures. Due to the fact that Hong Kong is largely susceptible to the western and global culture results from Hong Kong's link with the West during its colonial era and its nowadays status as the international city, it is justifiable to take the Western influence as a naturalistic and taken-for-granted phenolmenon (Lo 1964: 284). This makes the strategy of foreignization in translating English texts into Chinese possible and readily adopted by Daisy Chou and her colleagues.

Our case study implicates that the choice of strategies is significantly decided by the unbalanced cultural influence. The different strategies chosen in rendering texts of programmes of different origins tends to suggest that the English culture is taken as more influential than the Chinese culture in Hong Kong which can probably explain why foreignization is resorted to in translating the English texts into Chinese, while Chinese culture is found to be less influential on the English speaking community in Hong Kong, which results in the use of domestication of terms regarding the Chinese traditional theatres, for example using opera to refer to Jingju and Yueju in English. Therefore, regarding the performing arts under investigation, it seems the inequality of the influence of the Chinese and the Western cultures does exist in Hong Kong.

The impact of cultural inequality is not only reflected on the translation strategies deployed in handling publicity texts of different languages but also enhanced by the texts translated with 
different strategies. In our case, the English translations of the texts $f$ or the Chinese programmes prove that the domestication strategy reduces "the foreign text to target-language cultural values" (Venuti 1997: 242). The foreignness of the Chinese text, after being rendered in accordance with the preferences and values of the receiving culture, gets lessened and even erased. On the other hand, the Chinese translation of the texts about ballet witnesses the "ethonodeviant pressure" on the Chinese culture values to register the linguistic and cultural difference of the English culture (Venuti 1995: 20). Domestication undoubtedly helps a dominant culture to maintain its dominance. The outcome of such translation is conspicuous: the strong culture is strengthened, yet the weak weakened.

According to Venuti (1997), translation as the basic means of cultural exchange is at the same time an embodiment of the power struggle among cultures. Due to the dominance of English and American culture, translators alter the foreign text consciously and unconsciously to conform to the norms and conventions of AngloAmerican culture.

As teleological texts, the publicity-related articles on the website of HKAF are market oriented and the commercial purpose comes first in translation. So any translation in practice could not afford to overlook the fact about "Hong Kong as the ultimate consumer society, a place where money counts for everything and where everything is a commodity. ... where consumerism replaces politics as the principle form of cultural production and identification" (Lilley 1993: 263; 1998:31).

With generalization, the cultural peculiarities of Chinese texts are diluted greatly in the English translation, and this domesticating strategy avoids the translated texts to be too difficult for the English readers, who in fact do not know much about the Chinese culture and arts. So it is more possible for the arts in the Chinese culture to become accessible to the English readership when the introducing 
texts about the Chinese traditional artistic forms are rendered into a fluent natural-sounding one without too much cultural specific information. It is argued here that, not only domestication strategy in fact "assists in economic commoditization and consumption" (Gentler 1993: 37) but so does foreignization strategy.

\section{Conclusion}

In the present paper, a detailed comparison has been carried out to examine the different translation strategies and methods deployed in the Chinese to English translation of the publicity-related texts for Chinese programmes and in the English to Chinese translation of texts for Western programmes. The textual analysis reveals that specific textual practices reflect different strategies adopted in the cultural confrontation involved in translation. It has argued that to investigate translation of texts in the arts, it is essential to explicate the actual practice in the backdrop of cultural contexts and under the framework of cultural disparity and cultural exchange.

The inequality of influences of the Western culture and the Chinese culture in Hong Kong, a former colonial territory, exerts power and impact on the translation produced in the city, which is tangibly proven by the strategies and their corresponding methods deployed in practice. Not only "the strategies employed by the translator reflect the context in which texts are produced" (Bassnett \& Trivedi 1999: 6) but also the choice of strategies depends upon a right assumption about the real state of cultural inequality between the Chinese arts and the Western one. As far as texts intended for arts programme publicity is concerned, the right choice of strategies and the "methods along lines" (Venuti 1997: 242) is a guarantee of the success of the promotion of the arts events.

The impact wielded by the unbalanced influence of cultures on translation has been discussed in this paper. However, it is not 
attempted in this study to criticise the actual practice but to explain why different translation methods and strategies are adopted in producing TT between English and Chinese translation of texts in the arts. Neither does the author of the present paper want to advocate foreignization in translating Chinese to English or propose domestication of English texts. The foreignizing strategy advocated by Venuti needs further consideration in actual practice. As a theory that strategy is stimulating, but as a practice, it is perhaps not viable, especially for the C-E translation of texts in the arts for the purpose of publicity. What if the translated text rendered in this way might appear too foreign to be read on by the target readers? Obviously, this is not the radical cure of the disease so far. 


\section{Appendix}

\section{Texts Analyzed}

\section{Jingju : ST}

北京京剧院

京剧丑角宗师萧长华纪念系列

\section{内容}

鼻梁上的豆腐块, 或大或小, 可圆可方, 是戏曲中丑行, 也 称「小花脸」的标记。丑行戏路纵横，上自天子诸候，下到 流讯恶㾂，都入小花脸行当。戏行有云「无丑不成戏」。

在这不可或缺的戏曲行当中，有这一位不可或缺的人物：萧 长华先生 (1878-1967), 七十多年的艺术生命中, 他不仅创 造了二百多个脍采人口的丑角形象：蒋干、汤勤、杨衙内、 张别古、崇公道等等, 亦致力整理传统老戏和编创新剧, 丰 富了京剧的内容; 更重要的是积极培育戏曲人才, 先后担任 对京剧艺术持续发展影响深远的富连成科班总教习, 其后任 中国戏曲学校校长, 为京剧栽培不少人才。

2008 年适值萧先生 130 岁冥寿, 为了表扬他对京剧艺术的贡 献, 香港艺术节特别邀请了北京京剧院, 演出两个萧先生的 首本丑行戏: 《乌盆记》、《审头刺汤》和分别于两晚演出不同折 子的《龙潭鲍骆》, 以及尽显花面老旦功架的唱功戏《赤桑镇》。

阵容方面, 京剧院邀得萧先生亲传弟子郑岩连同程派青衣迟 小秋、谭派老生谭孝曾、马派老生朱强、雸派花脸陈俊杰等 压阵, 绝对不容错过!

\section{《乌盆记》}

老生和老丑为主的唱功戏。内容叙述穷老头张别古向赵大追 
148 Foreignized or Domesticated

讨旧账, 赵大以乌盆抵债, 乌盆内竟附有鬼魂, 更向老头哭 诉寃情, 老头便带着乌盆到包拯衙前告状, 使之沉寃得雪。

\section{《审头刺汤》}

改编清代著名剧作家李玉的「一捧雪」传奇, 描写裱画师汤 勤卖友求荣, 加害恩人莫怀古一家以取悦奸相严嵩, 并图把 莫之小妾雪艳据为己有, 借审辨人头真假而逼雪艳就范; 雪 艳将计就计, 假意允婚, 在洞房内把汤勤刺死, 以报夫仇。 《审头刺汤》在丑行的剧目中, 可算是最考工夫、最显实力的 一套。

\section{《赤桑镇》}

包拯年幼失去父母, 由嫂吴妙贞抚养成人。吴子为官, 贪赃 枉法, 包拯秉公惩处。吴妙贞赶到赤桑镇, 责包拯忘恩负义。 包拯晓以大义，吴妙贞感悟，叔嫂和睦如初。

\section{《龙潭鲍骆》}

《龙潭鲍骆》是一套热闹、火爆的大型武戏, 叙述鲍、骆两家 因故结怨, 经过种种冲突, 终而和解, 并携手共抗官兵的故 事。全剧由「嘉兴府」、「巴骆和」（或作「刺巴杰」） 和「四杰村」三个部分组成, 从头到尾都是连场开打, 三十 二般武艺尽出, 加上满台翻腾跌扑, 目不㗇给, 絶无冷场。 由于《龙潭鲍骆》规模庞大, 单是具名姓的角色都有二十多 个, 个个都要能打能翻, 一般戏班很少能有足够资源搬动全 本《龙潭鲍骆》。北京京剧院这次动用庞大人力物力, 把这套 久已絶迹舞台的传统大武戏重新整理, 并带来香港演出, 实 为京、港两地剧坛的盛事。

附中文字幕及英文故事大綱 


\section{Jingju : TT}

Beijing Opera

The Master of Chou: Xiao Changhua

\section{About this Programme}

\section{The 130th anniversary of the birth of Xiao Changhua}

A patch of white paint, like bean curd on the bridge of the nose, is the trade mark of the Chou, the comic actor in traditional Chinese opera. Of all the Chou actors, the greatest was Master Xiao Changhua.

To mark the 130th anniversary of Master Xiao"s birth, The Peking Opera House of Beijing present four works closely associated with his name. So don"t miss the chance to see some superb Beijing Opera and witness the comic legacy of a true Chou master.

\section{Special Remarks}

With Chinese surtitles and English scene synopses

\section{Ballet: ST}

Stuttgart Ballet

\section{Onegin}

\section{About this Programme}

\section{Onegin}

Celebrating the choreographic genius of John Cranko with two spectacular performances from his legendary repertoire. 
John Cranko"s narrative vision and grand-scale choreography inspired many dance greats - Marcia Haydée, William Forsythe and John Neumeier, to name but a few. A revolutionary in the classic ballet form, he is widely revered as a dance "master of masters".

Celebrating the 80th anniversary of Cranko"s birth and in honour of his pioneering contribution to dance, the 2008 Hong Kong Arts Festival proudly presents two of his most renowned and spectacular productions - Onegin and Swan Lake - performed by his home troupe, the Stuttgart Ballet.

"[Cranko] tells the story so fluently that the individual steps don"t seem to exist: They dissolve in feeling." Boston Globe

Based on the 19th century novel-in-verse, Eugene Onegin, by Alexander Pushkin, Onegin is an enduring tale of a broken heart, a deadly duel and passionate revenge. Rejected in her youth by the arrogant aristocrat Onegin, Tatiana buries her love and grows gracefully into womanhood. Many years later when Onegin realises his mistake and declares his love, the circumstances have changed, and Tatiana must painfully refuse his advances. The final pas de deux, in which Tatiana sends Onegin away, is a sensational tussle between love and moral duty and one of the most heart-wrenching scenes in all ballet. Onegin is set to Tchaikovsky"s music, arranged and orchestrated by Kurt-Heinz Stolze.

\section{John Cranko}

South African born John Cranko became artistic director of the Stuttgart Ballet in 1961. During his tenure he created numerous full-length "story ballets"- Romeo and Juliet 
(1962), Swan Lake (1963), Onegin (1965), and The Taming of the Shrew (1969), and transformed the local German troupe into a company of vast international standing.

Cranko"s theatrical vision led him to devise works with pronounced narratives, rich characterisations and elaborate stage designs. He reworked the classical leads into dance parts with visible character arcs and a wide range of expression.

\section{Stuttgart Ballet}

The modern Stuttgart Ballet has a long, artistic history that began in 1609 in the royal court of the Duke of Württemberg. Though unknown for many centuries outside of Germany, John Cranko"s appointment as artistic director, in 1961, ushered in a new era of international acclaim. On its Onegin tour of the US, in 1969, it was dubbed the "Stuttgart Ballet miracle" by enthusiastic critics. Following its successes, the company became inundated with invitations to perform.

When Reid Anderson became Artistic Director of the Stuttgart Ballet in 1996 he reassembled it, prompting critics to call it "The New Stuttgart Ballet". Anderson"s tenure has produced numerous critically acclaimed productions, both signature works from Cranko and new works from rising, young choreographers.

\section{Ballet: TT}

史图加芭蕾舞团《奥尼金》

芭蕾舞后 Marcia Haydée, 编舞大师 William Forsythe 'Jiří Kylián、

John Neumeier 恩师

廿世纪舞剧大师格兰高八十冥寿 


\section{Foreignized or Domesticated}

艺术节历史呈献 史图加演绎两大经典

芭蕾舞剧大师约翰. 格兰高, 领导史图加芭蕾舞团十二年, 一手成就史图加国际顶级舞团的地位, 创作多出经典舞剧, 被誉为廿世纪舞剧大师之一, 更为舞坛带来了芭蕾天后玛茜. 海 蒂、男星埃贡.马德森, 编舞大师威廉. 科西、约翰. 纽迈 亚、尤利. 季利安, 都在他鼓励下踏出编舞的第一步。

为纪念这位大师中的大师八十冥寿, 香港艺术节特别呈献其 两出精品一一香港舞台难得一见的《奥尼金》，及 2008 年艺 术节开幕节目, 被称为格兰高与史图加芭蕾舞团最大型制作 之一的《天鹅湖》。

《奥尼金》「格兰高的《奥尼金》如水银泻地, 一气呵成, 分不 清个别舞步，只因全已融化在情感中」《波士顿地球报》

芭蕾舞剧《奥尼金》是格兰高创作经典中的经典，根据普希金 的诗改编, 以柴可夫斯基的音乐编曲, 被誉为本世纪舞坛的 旷世杰作。

当年玩世不恭的奥尼金拒绝纯真少女泰坦妮亚的爱，多年后 再遇, 才知真爱谁属, 奈何心上人已作他人妇。格兰高选取 了普希金原著中一系列令人难忘的场面: 花园邂逅、闺中订 情、双雄决剑与蓦然回首, 手工精细的服装与格局宏大的布 景, 配以令人屏息的高难度芭蕾技巧, 细致地刻划人物的内 心世界，描绘感情的跌宕，两场荡气回肠的双人舞更列为舞 坛经典。1965 年首演时, 担演泰坦妮亚的玛茜. 海蒂, 光芒 四射, 是最令人着迷的芭蕾角色之一。

\section{约翰・格兰高 (1927-1973)}

格兰高 1961 年起出任史图加芭蕾舞团艺术总监, 成为他与舞 团历史的转捩点, 12 年间, 他为舞团编排了多出经典舞剧, 包括《奥尼金》、《天鹅湖》、《罗密欧与荣丽叶》及《驯悍记》, 
格兰高永不重复自己, 每一出作品都各有特色, 奠定他舞剧 大师的地位，为舞迷塑造玛茜。海蒂等芭蕾天后巨星外，亦 鼓励了一群才华横溢的年轻编舞一一威廉. 科西、约翰. 纽 迈亚、尤利. 季利安一一当今舞坛举足轻重的舞坛大师。

\section{史图加芭蕾舞团}

史图加芭蕾舞团保持国际顶尖舞团的地位凡四十年，舞团悠 久历史可追溯至 17 世纪初的芭蕾舞团, 1961 年, 约翰・格兰 高出任芭蕾舞总监, 开展了舞团光辉骄人的日子, 他创作的 经典舞剧, 把舞团提升为世界首屈一指的芭蕾舞团, 在纽约 巡回演出时更获誉为「史图加奇迹」。1973 年格兰高逝世, 玛茜. 海蒂不久接掌舞团, 至 1995 年卸任。1996 年起, 前 史图加芭蕾舞团成员雷德·安德逊出任舞团艺术总监, 他秉承 格兰高的路线, 演出舞团经典之余, 亦着重发展新编; 又致 力网罗出色的年轻舞蹈员, 保持舞团的活力, 将舞团推向新 高。

\section{References}

Bassnett, S. \& H. Trivedi. 1999. Postcolonial Translation: Theory and Practice. London \& New York: Longman.

Beaugrande, R. de. \& W. U. Dressler. 1981. Introduction To Text Linguistics. London \& New York: Longman.

Bland, A. 1976. A History of Ballet and Dance in the Western World. New York: Praeger Publishers.Gentzler, E. 1993. Contemporary Translation Theories, London \& New York: Routledge.

Gibbons, J. I. 1987. Code-mixing and Code Choice: A Hong Kong Case Study. Clevedon, Philadelphia: Multilingual Matters.

Goldstein, S. 2007. Drama Kings: Players and Publics in the Recreation of Peking Opera, 1870-1937. California: University of California Press.

Jacquemond, R. 1992. Translation and Culture Hegemony: The 
Case of French-Arabic Translation. London \& New York: Routledge.

Han, Z. (韩子满) 2000. “Cultural Disparity and Literal Translation”, Chinese Translators Journal 2, 39-43. (“文化失衡与文学翻 译”, 《中国翻译》2000 年第 2 期, 39-43。)

Hong Kong Arts Festival 2008, May 20. Available at URL $<$ http://www.hk.artsfestival.org/>

Lau, W. \& J. Tu. 2006. "Jing Ju: Unveiling the secrets of Peking opera", a lecture from Peking Opera Demonstration by The Little Pear Garden Collective in Canada, available at URL $<$ http://dlll.yorku.ca/chinese/china_week_06/China_week_06_p eargarden.htm>

Lilley, R. 1993. "Claiming identity: film and television in Hong Kong" History \& Athropology 6, 261-92.

Lin, T. B. et al.(eds.) 1979. Hong Kong: Economy, Social and Political Studies in Development, New York: M. E. Sharpe, Inc.

Liu, C. C. 1989. “The Language Scene in Hong Kong,” in Catriona Picken (ed.) The Translator's Handbook. London: Aslib.

Lo, H. L. 1964. Hong Kong and Western Cultures. Tokyo: Centre for East Asian Cultural Studies.

Lo, H. L. 1964. Hong Kong and Western Cultures. Tokyo: Centre for East Asian Cultural Studies.

Loh, D. (陸殿揚) 1958. Translation: Its Principles and Techniques (Book One), Beijing: Times Publishing.

Luke, K. K. \& J. C. Richards 1982. "English in Hong Kong: Functions and Status" in English World-Wide: A Journal of Varieties of English 3, 47-64.

Mackerras, C. P. 1976. "Theatre and the Taipings", Modern China, 2 (4): 473. Available at URL <http://www.jstor.org/sici?sici= 0097-7004\%28197610\%292\%3A4\%3C473\%3ATATT\%3E2.0. $\mathrm{CO} \% 3 \mathrm{~B} 2-\mathrm{N}>$

Osgood, C. 1975. The Chinese - A Study of a Hong Kong Community, Tuscon Arizona: The University of Arizona Press. 
Pang, K. F. 1992. End of an Era - A Portrait of Hong Kong Culture, Sinorama 102-4.

Pang, S. 2008. "What is Discourse", lecture notes of the course Translation of Texts in the Arts. Macao: University of Macau. 2008. "Participants in Discourse in the Arts", lecture notes for the course Translation of Texts in the Arts. Macao: University of Macau.

Robinson, D. 1997. Translation and Empire: Postcolonial Theories Explained. Manchester: St. Jerome.

Samovar, L. A. et al. 2000. Communication between Culture. Beijing: Foreign Language Teaching and Research Press.

Simon, S. 1997. Translation and Cultural Politics in Canada, in S Ramakrishna ed., Translation and Multilingualism. Delhi: Pencraft International.

Vinay, j. \& j. Darbelnet 1989. 'Translation Procedures', trans. by A. Chesterman, in A. Chesterman (ed), Readings in Translation Theory. Helsinki: Oy Finn Lectura Ab, 61-9.

Venuti, L. 1992. Rethinking Translation: Discourse, Subjectivity, Ideology. London \& New York: Routledge. 1995. The Translator's Invisibility: A History of Translation. London \& New York: Routledge. 1997. "The American Tradition", in M. Baker (ed.) 1997, The Routledge Encyclopaedia of Translation Studies. London \& New York: Routledge.

2000. The Translation Studies Reader. London \& New York: Routledge.

Wang, D. (王东风) 2000. “Cultural Position of Translated Literature and Translator"s Cultural Attitude", Chinese Translators Journal 4, 2-8. (“翻译文学的文化地位与译者的文化态度”, 《中 国翻译》2000 年第 4 期，2-8。)

Zhang, M. \& L. Pan (张美芳, 潘莉) 2009. “Introducing a Chinese Perspective on Translation Shift: A Comparative Study on Shift Models by Loh and Vinay \& Darbelnet", The Translator 15, 
156 Foreignized or Domesticated

351-7.

Zhao, Q. 2007. Jingju vs. Peking Opera. Available at URL $<\mathrm{http}$ ///www.danwei.org/internet/jingju_or_peking_opera_zhao qi.php> 